\title{
OPTIMASI ALGORITMA LEARNING VECTOR QUANTIZATION (LVQ) DALAM PENGKLASIFIKASIAN CITRA DAGING SAPI DAN DAGING BABI BERBASIS GLCM DAN HSV
}

\author{
Usman Sudibyo \\ Fakultas Ilmu Komputer, Program Studi Teknik Informatika \\ Universitas Dian Nuswantoro Semarang \\ Email: usman.sudibyo@dsn.dinus.ac.id \\ Desi Purwanti Kusumaningrum \\ Fakultas Ilmu Komputer, Program Studi Teknik Informatika \\ Universitas Dian Nuswantoro Semarang \\ Email: desi.purwanti@dsn.dinus.ac.id \\ Eko Hari Rachmawanto \\ Fakultas Ilmu Komputer, Program Studi Teknik Informatika \\ Universitas Dian Nuswantoro Semarang \\ Email: eko.hari@dsn.dinus.ac.id \\ Christy Atika Sari \\ Fakultas Ilmu Komputer, Program Studi Teknik Informatika \\ Universitas Dian Nuswantoro Semarang \\ Email: atika.sari@dsn.dinus.ac.id
}

\begin{abstract}
ABSTRAK
Meningkatnya kebutuhan daging sapi, berdampak pada harga daging sapi. Harga daging sapi yang terus menerus mengalami kenaikan, tentunya menyebabkan penurunan penjualan daging sapi. Untuk mengantisipasi hal tersebut, maka beberapa pedagang mencampurkan daging sapi dengan daging babi. Dipilihnya daging babi, karena harga daging babi lebih murah dan warna serta tekstur daging babi yang mirip dengan daging sapi. Secara kasat mata daging sapi dan daging babi sulit untuk dibedakan bagi orang awam. Oleh karena itu, perlu adanya sistem yang dapat membedakan kedua daging. Penelitian ini menggunakan metode klasifikasi untuk membedakan kedua daging. Metode klasifikasi menggunakan algoritma Learning Vector Quantization. Dan penelitian ini memiliki tiga tahapan utama seperti preprocessing, segmentasi warna, ekstraksi fitur, dan klasifikasi. Preprocessing digunakan untuk mendapatkan Region of Interest (ROI) dengan memotong citra dan mengubah ukuran citra. Segmentasi warna menggunakan metode HSV untuk mendapatkan kedalaman warna citra dan ekstraksi fitur mengguakan Gray Level Co-occurrence Matrix (GLCM) untuk mendapatkan fitur dari kontras, korelasi, energi, dan homogenitas. Hasil klasifikasi dengan algoritma LVQ mendapatkan akurasi tertinggi 76,25\%. Algoritma telah diuji dengan MSE untuk mengetahui minimum error dan PSNR digunakan sebagai pengukuran kualitas citra pengolahan.
\end{abstract}

Kata kunci: klasifikasi daging, LVQ, HVS, GLCM, MSE, PSNR.

\begin{abstract}
The increasing need of beef, has an impact on the price of beef. The price of beef that continues to increase, of course, leads to a decrease in beef sales. To anticipate this, then some traders mixing beef with pork. The choice of pork, because the price of pork is cheaper and the color and texture of pork similar to beef. In plain beef and pork are difficult to distinguish for the layman. Therefore, the need for a system that can distinguish the two flesh. This study uses the classification method to distinguish the two flesh. Classification method using Learning Vector Quantization algorithm. And this study has three main stages such as preprocessing, color segmentation, feature extraction, and classification. Preprocessing is used to get Region of Interest (ROI) by cutting the image and resizing the image. Color segmentation using HSV method to get color depth image and feature extraction using the Gray Level Co-occurrence Matrix $(G L C M)$ to get features of contrast, correlation, energy, and homogeneity. Result of classification using LVQ method get highest accuracy 76,25\%. The algorithm was tested using MSE to calculate the minimum error and PSNR used as image quality measurement.
\end{abstract}

Keywords: beef classification, LVQ, HSV, GLCM, MSE, PSNR. 


\section{PENDAHULUAN}

Daging sapi adalah salah satu bahan makanan yang baik untuk dikonsumsi, banyaknya kandungan zat gizi dan protein yang terdapat pada daging membuat sebagian besar orang memilih daging sapi sebagai salah satu bahan makanan yang baik untuk dikonsumsi sehari-hari. Hal ini yang membuat daging sapi dipilih sebagai salah satu daging yang paling diminati dibandingkan daging lainnya [1]. Meningkatnya konsumsi dan kebutuhan daging sapi dipasaran, menimbulkan meningkatnya harga daging sapi dari tahun ketahun. Peningkatan harga daging sapi biasanya terjadi pada hari-hari besar seperti hari raya idul fitri dan hari raya lainnya. Dengan peningkatan ini, membuat beberapa pedagang daging sapi mengalami kerugian dan mengalami pemerosotan pembelian daging sapi. Untuk menekan kerugian tersebut, pedagang daging sapi biasanya mengurangi penjualan daging agar tidak mengalami kerugian yang besar. Namun, ada pula pedagang yang memanfaat kesempatan ini untuk meraup keuntungan yang lebih besar dengan melakukan kecurangan yang merugikan konsumennya, yaitu dengan mencampuran daging sapi dengan daging babi. Harga daging babi yang lebih murah dibandingan dengan harga daging sapi membuat daging babi dipilih sebagai bahan daging campurannya. Apalagi daging babi memiliki warna dan tekstur daging yang hampir sama dengan daging sapi. Dengan warna dan tekstur daging yang samar-samar, membuat kebanyakan pembeli terkecoh dan mengalami kesulitan untuk membedakan antara kedua daging tersebut. Apalagi untuk orang-orang yang memiliki keterbatasan penglihatan seperti rabun dan buta akan warna.

Dengan adanya kecurangan yang dilakukan oleh beberapa pedagang daging dan untuk mengurangi kecurangan tersebut maka parlu adanya sistem yang dapat mengenali antara kedua daging. Salah satunya adalah dengan memanfaatkan pengolahan citra digital, dengan pengolahan citra digital ini maka akan dapat membuat sebuah sistem pengenalan daging secara komputerisasi yang bisa membedakan antara daging sapi dengan daging babi seperti halnya manusia [2]. Dalam pengolahan citra ada beberapa proses atau tahap yang bisa dilakukan untuk mengetahui karakteristik pada suatu citra yang meliputi preprocessing, segmentasi, filtering, ektraksi, klasifikasi, dan lain sebagainya. Karena cara untuk membedakan antara daging sapi dengan daging babi bisa dilihat dari segi warna daging dan tekstur daging maka pada penelitian ini akan melalui tahapan pengenalan daging meliputi preprocessing, segmentasi warna, ekstraksi fitur, dan klasifikasi.

Preprocessing merupakan proses pengolahan citra untuk mendapatkan citra Region of Interest (ROI) seperti pemotongan citra (cropping) maupun memperkecil ukuran citra (resize). Pada penelitian ini akan melakukan preprocessing dengan tujuan untuk mendapatkan citra ROI dengan proses pemotongan citra (cropping) sesuai dengan ukuran daging, penghilangan background pada citra (citra yang mempunyai background), dan mengubah ukuran citra dengan ukuran 500x500 piksel. Segmentasi warna merupakan proses pengolahan citra yang melakukan pendekatan pada daerah yang bekerja dengan menganalisis nilai warna dari setiap piksel pada citra dan membagi citra tersebut sesuai dengan fitur yang diinginkan. Pada penelitian sebelumnya yang dilakukan oleh Elvia Budianita, Jasril, dan Lestari Handayani pada tahun 2015 menggunakan HSV menyatakan bahwa dengan menggunakan metode HSV menghasilkan akurasi yang baik, dengan akurasi tertinggi sebesar $73,375 \%$ sampai dengan $88,75 \%$. Nilai akurasi yang didapat dari tiga buah nilai histogram yang terdiri dari histogram Hue, Saturation, dan Value. Pembuatan histogram dilakukan pada citra RGB yang telah dikonversi HSV terlebih dahulu [1]. Ekstraksi fitur merupakan metode analisis yang dibagi menjadi metode statistik dan struktural dimana pendekatan dilakukan berdasarkan garis paralel jarak teratur dan biasanya ditandai tidak hanya oleh nilai abu-abu pada piksel tertentu tetapi juga oleh pola di lingkungan sekitar piksel. Sedangkan klasifikasi adalah proses pengelompokkan sampel dari data training ke dalam kategori (kelas) berdasarkan jarak terdekat antara sampel dengan data testing.

\section{METODOLOGI PENELITIAN}

\subsection{Preprocessing}

Preprocessing merupakan tahapan yang bertujuan untuk mendapatkan Region Of Interest (ROI) dengan cara memotong citra, mengubah ukuran gambar, dan lain sebagainnya [2]. Pada penelitian ini, diawali dengan pemotongan (cropping) citra asli sesuai dengan ukuran daging. Kemudian citra yang sudah dipotong (crop) akan dihilangkan backgroundnya untuk mendapatkan citra dagingnya. Dan proses yang terakhir adalah dengan mengubah semua ukuran citra menjadi 500x500 piksel. Tahapan ini untuk mendapatkan citra pengolahan yang lebih baik dari sebelumnya. Dan hasil yang diharapkan dapat menghasilkan akurasi yang tinggi. 


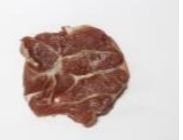

a

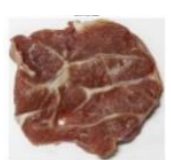

$\mathrm{b}$

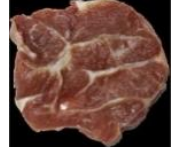

c

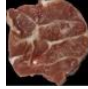

d

Gambar 1. Sampel Citra Daging Sapi: a. Citra Asli, b. Citra Cropping, c. Citra Tanpa Background, d. Citra Resize

\subsection{Hue, Saturation, Value (HSV)}

HSV terdiri dari tiga parameter seperti Hue, Saturation, dan Value. Dari masing-masing paramater HSV memiliki karakteristik seperti menyatakan warna, menyatakan pencahayaan, dan menyatakan kedalaman cahaya [3]. Untuk memperoleh nilai dari HSV terlebih dahulu konversi citra RGB kedalam HSV, dengan rumusan sesuai persamaan 1 sampai persamaan 7 sebagai berikut :

$H=\tan \left[\frac{3(G-B)}{(G-B)+(R-B)}\right]$

$S=1-\left[\frac{\min (R G B)}{V}\right]$

$V=\left[\frac{R+G+B}{3}\right]$

Perumusan diatas, apabila nilai yang didapat $\mathrm{S}=0$ maka nilai $\mathrm{H}$ tidak dapat ditentukan. Untuk itu diperlukan normalisasi citra RGB dengan perumusan seperti berikut :

$r=\left(\frac{R}{255}\right), g=\left(\frac{G}{255}\right), b=\left(\frac{B}{255}\right)$

\section{Dimana :}

$\mathrm{R}=$ nilai Red belum ternormalisasi

$\mathrm{r}=$ nilai red ternormalisasi

$\mathrm{G}=$ nilai Green belum ternormalisasi

$\mathrm{g}=$ nilai Green ternormalisasi

$\mathrm{B}=$ nilai Blue belum ternormalisasi

$\mathrm{b}=$ nilai Blue ternormalisasi

Setelah nilai citra RGB ternormalisasi. Citra RGB dapat dikonversi kedalam citra HSV. Perumusan yang digunakan sebagai berikut :

$V=\max$ 
Dimana nilai maximum didapat dari perhitungan persamaan dibawah ini.

$$
\begin{aligned}
& S=\left\{j i k a_{t i d a k,\left\{\frac{\max -\min }{V}\right\}}^{a a, V=\min }\right\} \\
& H=\left\{\begin{array}{l}
\left.j i k a_{60 x}^{0 \rightarrow v=\min } \frac{g-r}{\max -\min } x \bmod 6\right) \rightarrow v=r \\
j i k a_{60 x\left[4+\frac{b-r}{s x v}\right] \rightarrow v=b}^{60 x\left[2+\frac{b-r}{s x v}\right] \rightarrow v=g}
\end{array}\right. \\
& H+360 \rightarrow H<0
\end{aligned}
$$

Dimana:

$\mathrm{V}=$ menyatakan nilai Value

$\mathrm{S}=$ menyatakan nilai saturation

$\mathrm{H}=$ menyatakan nilai Hue

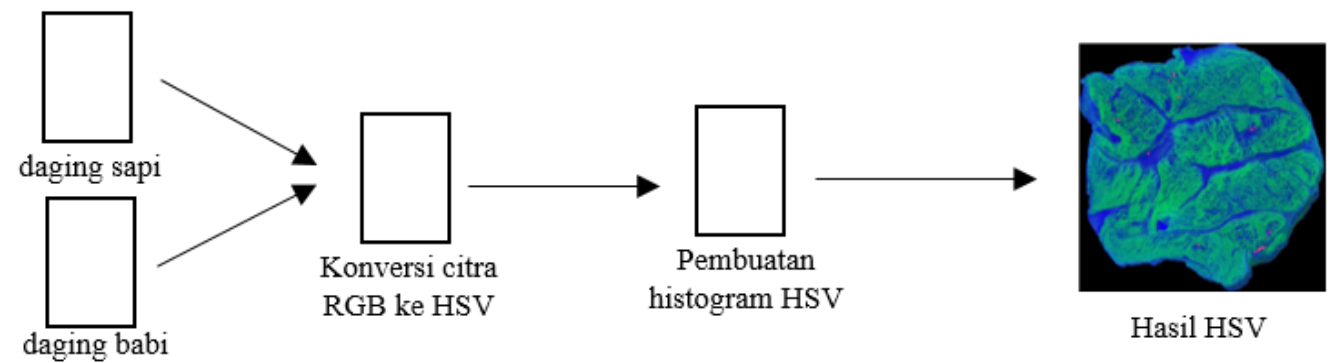

Gambar 2. Flowchart Segmentasi Warna HSV

\subsection{Gray Level Co-occurance Matrix (GLCM)}

GLCM merupakan teknik untuk mendapatkan nilai statistik orde kedua. Dimana proses awal membuat area kerja matrik dan menentukan nilai sudut dan jarak terdekat [3][4]. penelitian ini menggunakan sudut $0^{\circ}, 45^{\circ}, 90^{\circ}$, dan $135^{\circ}$ dengan jarak 1 . Setelah itu mendapatkan nilai matrik kookurensi. Nilai matrik kookurensi di normalisasi untuk diubah kedalam bentuk probabilitas. Dengan ternormalisasi matrik kookurensi, ekstraksi fitur dapat dilakukan. Contrast merupakan perhitungan yang berhubungan dari jumlah keberagaman intensitas grayscale pada citra. Correlation merupakan perhitungan untuk memberikan petunjuk dengan adanya struktur linier dalam citra dengan menunjukkan ukuran ketergantungan linier derajat keabuan pada citra. Energy digunakan untuk menentukan intensitas keabuan dengan ukuran konsentrasi pasangan tertentu pada matriks. Sedangkan homogenity digunakan untuk menentukan jumlah level keabuannya akan semakin tinggi jika seragam dan invers GLCMnya tinggi. Contoh perhitungan GLCM dengan persamaan 8 sampai persamaan 11 telah dilakukan sesusai objek penelitian sesuai Tabel 1 .

$$
\begin{aligned}
& \text { Con }=\sum_{x} \sum_{y}(x-y)^{2} p(x, y) \\
& \text { Corr }=\sum_{x} \sum_{y} \frac{(x-\mu x)(y-\mu y) p(x, y)}{\sigma x \sigma y} \\
& \text { Energy }=\sum_{x} \sum_{y} p(x, y)^{2} \\
& \text { Hom }=\sum_{x} \sum_{y} \frac{p(x, y)}{1+|x-y|}
\end{aligned}
$$

\footnotetext{
Dimana:

Con $\quad$ kontras
} 


$$
\begin{array}{ll}
\text { Corr } & =\text { korelasi } \\
x & =\text { Nilai baris pada matriks kookurensi } \\
y & =\text { Nilai kolom pada matriks kookurensi } \\
p(x, y) & =\text { Nilai baris }(\mathrm{x}) \text { dan kolom (y) pada matriks kookurensi } \\
\mu x & =\text { Perhitungan rata-rata nilai baris, dengan } x=\sum_{x} \sum_{y} x p(x, y) \\
\mu y & =\text { Perhitungan rata-rata nilai kolom, dengan } y=\sum_{y} \sum_{y} y p(x, y) \\
\sigma x & =\text { Variansi pada matrik x, dimana } x=\sum_{x} \sum_{y}(x-\mu x)^{2} p(x, y) \\
\sigma y & =\text { Variansi pada matrik y, dimana } y=\sum_{x} \sum_{y}(y-\mu y)^{2} p(x, y)
\end{array}
$$

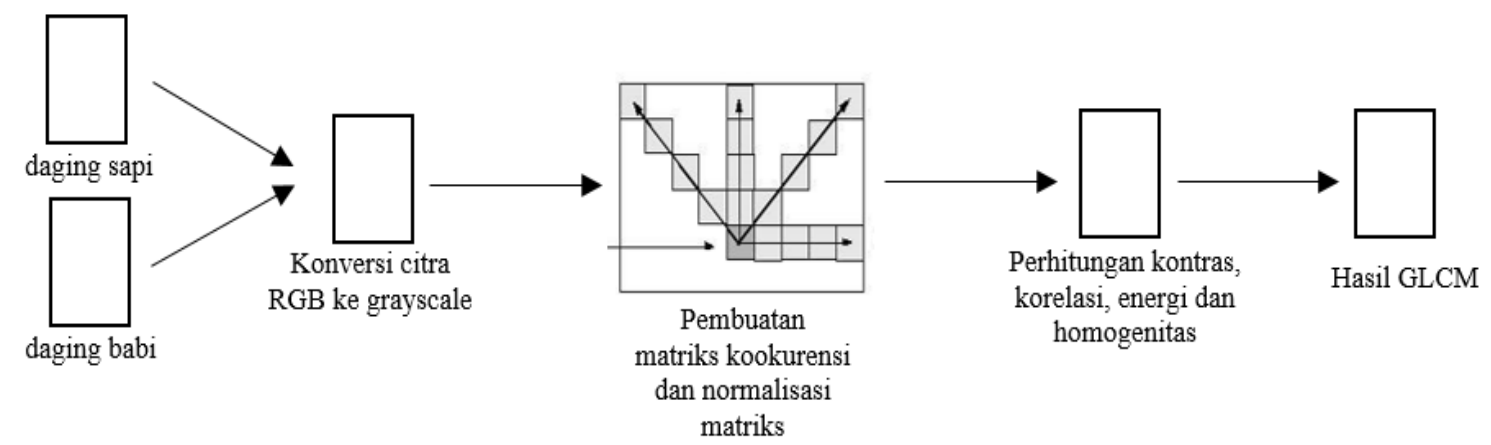

Gambar 3. Flowchart Ekstraksi Fitur GLCM

Tabel 1. Contoh perhitungan nilai GLCM pada objek penelitian

\begin{tabular}{cccccc}
\hline Citra asli & contrast & correlation & Energy & homogenity & average \\
\hline & 0,0043 & 1,8834 & 0,1846 & 0,8831 & 0,7389
\end{tabular}

\subsection{Learning Vector Quantization (LVQ)}

LVQ adalah jaringan syaraf yang bertipe arsitektur jaringan lapis-tunggal umpan-maju (Single Layer Feedforward) yang meliputi unit inputan dan unit outputan [5], [6]. Lapisan kompetitis akan secara otomatis belajar untuk mengklasifikasikan vektor-vektor masukan. Kelas-kelas yang didapatkan sebagai hasil dari lapisan kompetitif ini hanya tergantung pada jarak antara vektor masukan. Jika 2 vektor masuk mendekati sama, maka lapisan kompetitif akan meletakkan kedua vektor masukan tersebut kedalam kelas yang sama. Diamsumsikan bahwa serangkaian pola pelatihan dengan klasifikasi yang tersedia bersama dengan distribusi awal referensi sesuai Gambar 4. Pada penelitian ini akan digunakan bagan operasi LVQ sesuai penelitian yang telah dilakukan oleh [7] sebagai berikut. 


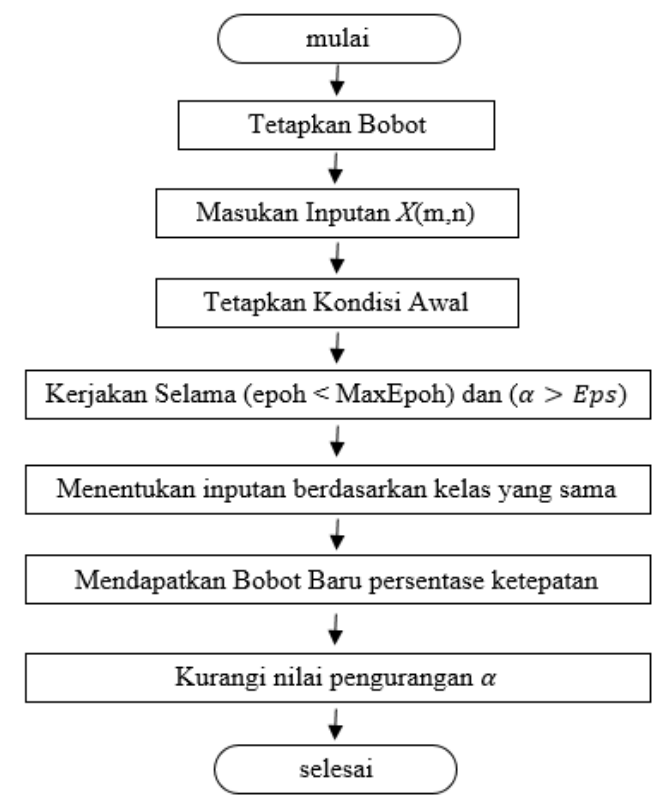

Gambar 4. Flowchart Klasifikasi Citra Yang Diusulkan

Sesudah pelatihan jaringan LVQ mengkalsifikasi vektor [8] masukan dengan menugaskan ke kelas yang sama sebagai unit keluaran, sedangkan yang mempunyai vector referens diklasifikasikan sebagai vektor masukan [9], [10]. Dalam hal ini sehimpunan pola yang klasifikasinya diketahui dan diberikan bersama distribusi awal vektor masukan dalam kelas yang sama dengan unit keluaran yang memiliki bobot (referensi) yang paling dekat dengan vektor masukan.

\subsection{Evaluasi Eksperimen}

Untuk mengukur tingkat akurasi Learning Vector Quantization (LVQ), peneliti menggunakan metode Mean Squared Error (MSE) dan Peak Signal to Noise Ratio (PSNR). Semakin kecil MSE semakin baik akurasi yang didapatkan dan semakin tinggi MSE maka semakin buruk akurasi yang didapatkan. Dan berikut adalah perumusan dari ketiga penghitungan evaluasi tingkat akurasi Learning Vector Quantization (LVQ) sesuai persamaan 12 sampai persamaan 14 di bawah ini:

$M S E=\frac{1}{m n} \sum_{i=0}^{m-1} \sum_{j=0}^{n-1}(i(i, j)-k(i, j))^{2}$

Keterangan :

$m \quad$ = jumlah baris

$n \quad=$ jumlah kolom

$i(i, j) \quad=$ nilai bobot awal

$k(i, j) \quad=$ nilai bobot akhir (bobot hasil klasifikasi)

$P S N R=10 \log 10\left(\frac{\max _{i}^{2}}{M S E}\right)$

Keterangan :

$\begin{array}{ll}\operatorname{PSNR}_{\max _{i}} & =\text { nilai PSNR citra }(\text { dalam dB) } \\ \operatorname{MSE} & =\text { nilai maximum piksel citra } \\ & =\text { nilai MSE }\end{array}$ 
Parameter PSNR bernilai sebaliknya, semakin besar parameter PSNR maka semakin bagus kualitas citra dengan citra asli.

$$
\text { Akurasi }=\frac{\text { data_benar }}{\text { jumlah_seluruh_data }} \times 100 \%
$$

Perhitungan akurasi ini, untuk menghitung hasil persentase kebenaran dalam proses klasifikasi terhadap data uji (testing).

\section{HASIL DAN PEMBAHASAN}

Proses klasifikasi dilakukan menggunakan metode learning vector quantization (LVQ) dengan dataset latih (training) sebanyak 260 citra dan dataset uji (testing) sebanyak 80 citra. Pada Tabel pengujian dibawah, peneliti menunjukan hasil persentase akurasi yang didapat dari ketiga metode. Penelitian ini menggunakan learning rate secara acak dari 0 - 1 dengan eph $0-1$ dan epoch 100 . Namun dalam penelitian ini mengambil beberapa sampel dari learning rate dan eph yang menghasilkan akurasi terbaik. Sebelum data diproses maka gambar asli akan diproses untuk penghilangan background, hasil operasi ditunjukkan pada Gambar 5, sedangkan GUI dari aplikasi klasifikasi daging sapi dan babi ni telah diuji coba dengan bahasa pemrograman Matlab.

Tabel 2. Uji citra dengan learning rate 0,1 dengan eph 0,1 dan epoch 100

\begin{tabular}{cccccc}
\hline $\begin{array}{c}\text { Learning } \\
\text { Rate }\end{array}$ & Eph & Epoch & MSE & PSNR & Akurasi \\
\hline 0,1 & 0,1 & 100 & 0,4612 & 51,4915 & $46,25 \%$ \\
0,2 & 0,1 & 100 & 0,4961 & 51,1749 & $50 \%$ \\
0,3 & 0,1 & 100 & 0,4651 & 51,4552 & $48,75 \%$ \\
0,4 & 0,1 & 100 & 0,4845 & 51,2779 & $51,25 \%$ \\
0,5 & 0,1 & 100 & 0,4961 & 51,1749 & $51,25 \%$ \\
\hline
\end{tabular}

Pada Tabel 2 menunjukan learning rate dari 0,1 sampai 0,5 dengan memiliki eph 0,1 . Dengan memperoleh nilai akurasi tertinggi pada learning rate 0,4 dan 0,5 dengan persentase 51,25\%. Sedangkan nilai akurasi terendah pada learning rate 0,1 dengan persentase $46,25 \%$. Perubahan nilai yang didapat dari hasil perhitungan GLCM dapat dilihat pada Gambar 5.

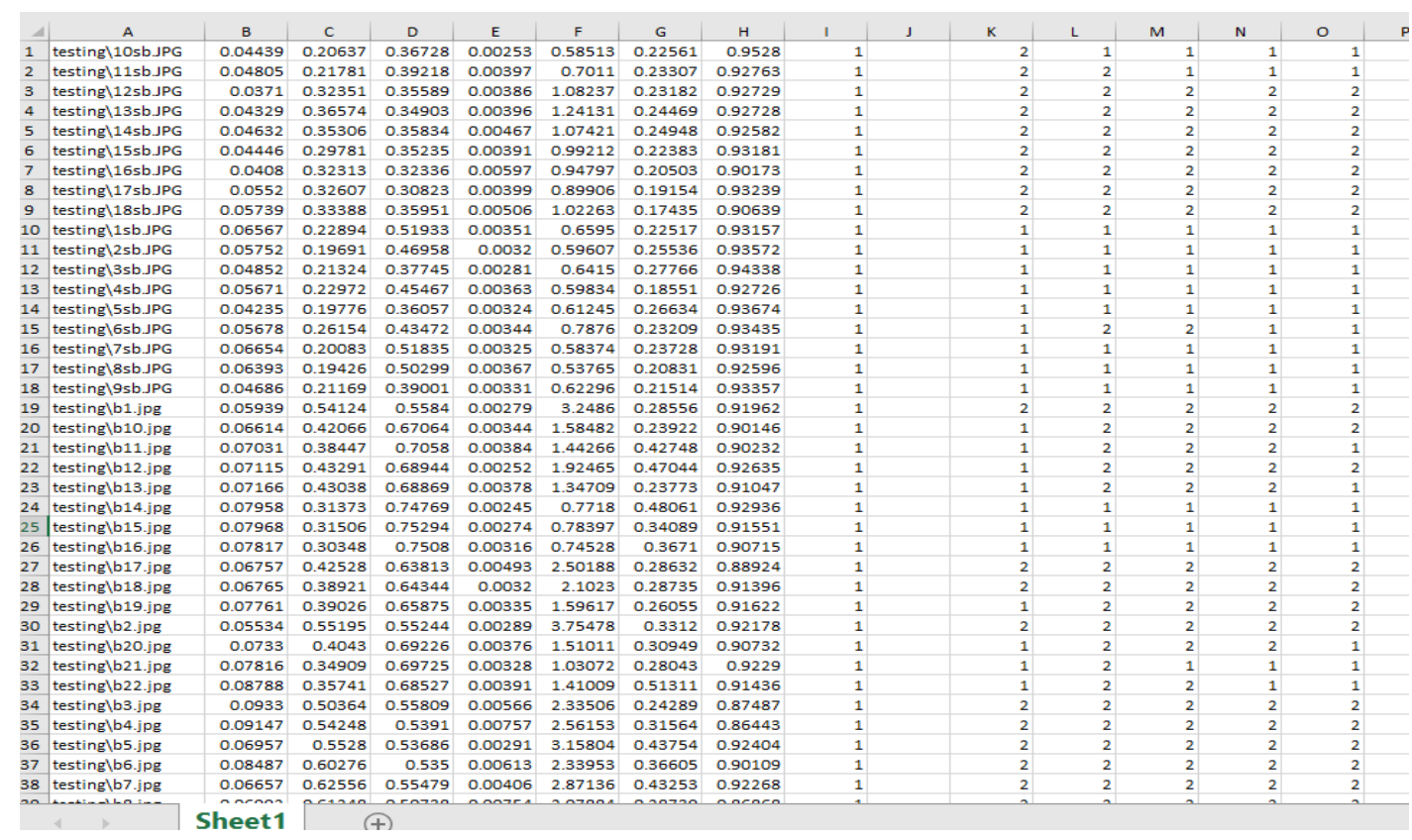

Gambar 5. Perubahan Nilai Piksel Citra Setelah Melalui Proses Penghilangan Background 
Pada Gambar 5 dapat diketahui bahwa proses perhitungan data citra daging babi dan daging sapi dimulai dari preprosesing dengan melakukan cropping gambar dan proses background substraction yang diubah ke warna hitam. Proses selanjutnya yaitu melakukan segmentasi warna menggunakan Hue, Saturation, Value (HSV) dan perhitungan nilai GLCM citra. Setelah nilai GLCM muncul, maka citra dapat diklasifikasikan dengan Learning Vector Quantization (LSV) pada Gambar 6. Dalam penelitian ini dilakukan uji LVQ dengan epoch 100, untuk learning rate yang digunakan telah divariasikan mulai yaitu 0,1 dan 0,01 sedangkan eph yang digunakan juga bervariasi yaitu 0,1 sampai dengan 0,5 . Hal ini dilakukan untuk mengetahui akurasi tertinggi.

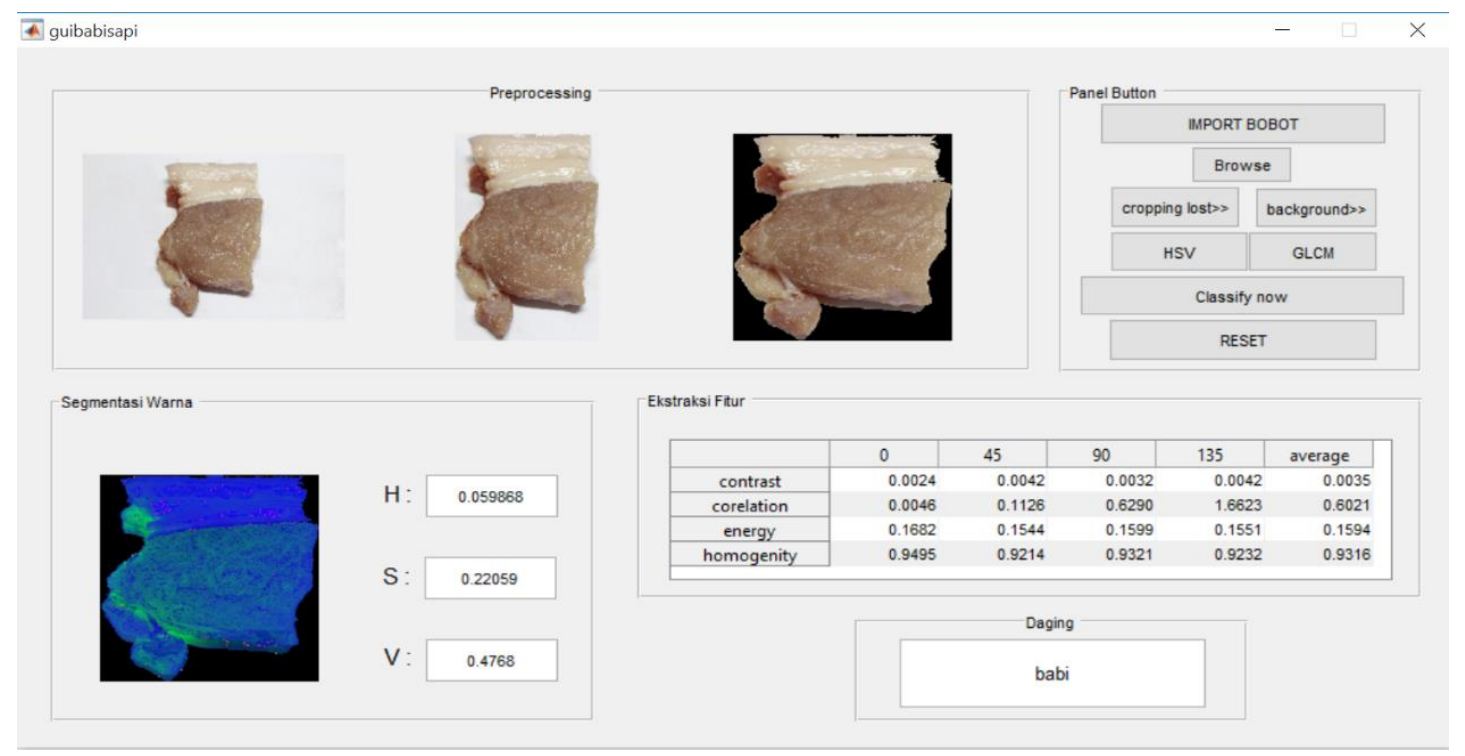

Gambar 6. Flowchart Klasifikasi Citra Yang Diusulkan

Tabel 3. Uji citra dengan learning rate 0,01 dengan eph 0,1 dan epoch 100

\begin{tabular}{cccccc}
\hline $\begin{array}{c}\text { Learning } \\
\text { Rate }\end{array}$ & Eph & Epoch & MSE & PSNR & Akurasi \\
\hline 0,01 & 0,1 & 100 & 0,2519 & 54,1179 & $76,25 \%$ \\
0,02 & 0,1 & 100 & 0,4612 & 51,4915 & $53,87 \%$ \\
0,03 & 0,1 & 100 & 0,4612 & 51,4915 & $45 \%$ \\
0,04 & 0,1 & 100 & 0,4612 & 51,4915 & $46,25 \%$ \\
0,05 & 0,1 & 100 & 0,4651 & 51,4552 & $46,25 \%$ \\
\hline
\end{tabular}

Tabel 4. Uji citra dengan learning rate 0,01 dengan eph 0,4 dan epoch 100

\begin{tabular}{cccccc}
\hline $\begin{array}{c}\text { Learning } \\
\text { Rate }\end{array}$ & Eph & Epoch & MSE & PSNR & Akurasi \\
\hline 0,01 & 0,4 & 100 & 0,5039 & 51,1076 & $57,50 \%$ \\
0,02 & 0,4 & 100 & 0,3295 & 52,4528 & $65 \%$ \\
0,03 & 0,4 & 100 & 0,4884 & 51,2433 & $53,75 \%$ \\
0,04 & 0,4 & 100 & 0,3953 & 52,1610 & $50 \%$ \\
0,05 & 0,4 & 100 & 0,3953 & 52,1610 & $50 \%$ \\
\hline
\end{tabular}

Pada Tabel 3 dan Tabel 4 menunjukan learning rate dari 0,01 sampai 0,05 dengan memiliki eph yang berbeda dalam perhitungan akurasi. Akurasi tertinggi pada learning rate 0,01 dengan persentase 76,25\% dan nilai akurasi terendah pada learning rate 0,03 dengan persentase $45 \%$. Persentase tinggi maupun rendah terdapat pada eph yang sama yakni epoch 100 dan eph 0,1 dan 0,4 serta learning rate pada 0,01. 
Tabel 5. Uji citra dengan learning rate 0,01 dengan eph 0,2 dan epoch 100

\begin{tabular}{cccccc}
\hline $\begin{array}{c}\text { Learning } \\
\text { Rate }\end{array}$ & Eph & Epoch & MSE & PSNR & Akurasi \\
\hline 0,01 & 0,001 & 0,3 & 100 & 0,4922 & $51,2090 \%$ \\
0,02 & 0,002 & 0,3 & 100 & 0,4845 & $51,2779 \%$ \\
0,03 & 0,003 & 0,3 & 100 & 0,4884 & $51,2433 \%$ \\
0,04 & 0,004 & 0,3 & 100 & 0,4884 & $51,2433 \%$ \\
0,05 & 0,005 & 0,3 & 100 & 0,4806 & $51,3128 \%$ \\
\hline
\end{tabular}

Tabel 6. Uji citra dengan learning rate 0,01 dengan eph 0,3 dan epoch 100

\begin{tabular}{cccccc}
\hline $\begin{array}{c}\text { Learning } \\
\text { Rate }\end{array}$ & Eph & Epoch & MSE & PSNR & Akurasi \\
\hline 0,01 & 0,001 & 0,02 & 100 & 0,4922 & $51,2090 \%$ \\
0,02 & 0,002 & 0,02 & 100 & 0,4884 & $51,2433 \%$ \\
0,03 & 0,003 & 0,02 & 100 & 0,4884 & $51,2433 \%$ \\
0,04 & 0,004 & 0,02 & 100 & 0,4845 & $51,2779 \%$ \\
0,05 & 0,005 & 0,02 & 100 & 0,5039 & $51,1076 \%$ \\
\hline
\end{tabular}

Tabel 7. Uji citra dengan learning rate 0,01 dengan eph 0,5 dan epoch 100

\begin{tabular}{cccccc}
\hline $\begin{array}{c}\text { Learning } \\
\text { Rate }\end{array}$ & Eph & Epoch & MSE & PSNR & Akurasi \\
\hline 0,01 & 0,001 & 0,05 & 100 & 0,4884 & 51,2433 \\
0,02 & 0,002 & 0,05 & 100 & 0,4845 & 51,2779 \\
0,03 & 0,003 & 0,05 & 100 & 0,3992 & 52,1186 \\
0,04 & 0,004 & 0,05 & 100 & 0,3178 & 53,1089 \\
0,05 & 0,005 & 0,05 & 100 & 0,2364 & 54,3937 \\
\hline
\end{tabular}

Tabel 5, tabel 6 dan tabel 7 menunjukan learning rate dari 0,001-0,005 dengan memiliki eph yang berbeda. Dengan memperoleh nilai akurasi tertinggi pada learning rate 0,005 dengan persentase $75 \%$. dan nilai akurasi terendah pada learning rate 0,002 dengan persentase 55\%. Pada Tabel 3 dan Tabel 4, diketahui bahwa nilai akurasi yang diperoleh paling rendah yaitu $45 \%$ dan tertinggi $75,25 \%$. Rata-rata nilai akurasi yang diperoleh berkisar antara $51 \%$.

\section{KESIMPULAN}

Berdasarkan penilitian yang telah dilakukan maka pada penelitian ini memberi kesimpulan bahwa hasil dari tinggi atau rendahnya nilai akurasi yang didapat, tidak dipengaruhi oleh tinggi atau rendahnya learning rate maupun eph-nya. Preprocessing yakni dengan cropping otomatis pada citra sesuai bentuk daging, lalu penghilangan background pada citra, dan resize citra dengan ukuran 500x500 mampu melakukan proses pemisahan citra daging dengan baik. Segmentasi warna HSV yang diambil dari citra ROI dapat digunakan untuk proses klasifikasi. Nilai yang didapat dari 3 parameter HSV yakni Hue, Saturation, dan Value, dimana nilai tertinggi terdapat pada parameter Hue. Ekstrasi fitur GLCM orde dua dengan 4 parameter yakni contrast, corelation, energy, dan homogenity menggunakan sudut $0^{0}, 45^{\circ}, 90^{\circ}$, dan $135^{\circ}$ dapat membantu proses klasifikasi dengan baik. Hasil klasifikasi menggunakan learning vector quantization (LVQ) menghasilkan nilai akurasi tertinggi 76,25\% pada learning rate $=0,01$ dengan eph 0,1 dan epoch $=100$. Kesalahan yang paling banyak terdapat pada citra daging babi yang tercropping secara manual, sedangkan untuk citra berbackground hanya mengalami sedikit kesalahan. Hal ini ditunjukan berdasarkan persentase kebenaran dari akurasi yang didapat.

\section{DAFTAR PUSTAKA}

[1] E. Budianita, J. Jasril, and L. Handayani, "Implementasi Pengolahan Citra dan Klasifikasi K-Nearest Neighbour Untuk Membangun Aplikasi Pembeda Daging Sapi dan Babi Berbasis Web,” J. Sains dan Teknol. Ind., vol. 12, no. Vol 12, No 2 (2015): Juni 2015, pp. 242-247, 2015.

[2] L. Bing and W. Wang, "Sparse Representation Based Multi-Instance Learning for Breast Ultrasound Image Classification," Comput. Math. Methods Med., vol. 2017, pp. 1-10, 2017.

[3] O. R. Indriani, E. J. Kusuma, C. A. Sari, E. H. Rachmawanto, and D. R. I. M. Setiadi, "Tomatoes Classification Using K-NN Based on GLCM and HSV Color Space," in International Conference on Innovative and Creative Information Technology (ICITech), 2017, pp. 1-6.

[4] T. Sutojo, P. S. Tirajani, D. R. I. M. Setiadi, C. A. Sari, and E. H. Rachmawanto, "CBIR for 
classification of cow types using GLCM and color features extraction," in 2017 2nd International conferences on Information Technology, Information Systems and Electrical Engineering (ICITISEE), 2017, pp. 182-187.

[5] S. N. H. Sheikh Abdullah et al., "Round Randomized Learning Vector Quantization for Brain Tumor Imaging," Comput. Math. Methods Med., vol. 2016, pp. 1-19, 2016.

[6] A. C. Agustina, S. Suwarno, and U. Proboyekti, "Pengenalan Aksara Jawamenggunakan Learning Vector Quantization ( Lvq )," no. 1, 2009.

[7] Z. Lai and H. Deng, "Multiscale High-Level Feature Fusion for Histopathological Image Classification," Comput. Math. Methods Med., vol. 2017, pp. 1-6, 2017.

[8] J. Yang, S. Li, and W. Xu, "Active learning for visual image classification method based on transfer learning," IEEE Access, vol. 3536, no. c, pp. 1-1, 2017.

[9] G. Ramadhan, E. C. Djamal, and T. Darmanto, "Klasifikasi Identitas Wajah Untuk Otorisasi Menggunakan Deteksi Tepi dan LVQ," Semin. Nas. Apl. Teknol. Inf. 2016 Yogyakarta, pp. 37-41, 2016.

[10] A. A. Kasim and A. Harjoko, "Klasifikasi Citra Batik Menggunakan Jaringan Syaraf Tiruan Berdasarkan Gray Level Co- Occurrence Matrices ( GLCM )," Semin. Nas. Apl. Teknol. Inf. Yogyakarta, 21 Juni 2014, pp. 7-13, 2014. 